8. Согрин В.В. США в XX-XXI веках. Либерализм. Демократия. Империя. М.: Издательство «Весь Мир», 2015. 592 c.

9. Inaugural Address. January 20, 1993 // Public Papers of the Presidents of the United States: William J. Clinton (1993, Book I). P. 2.

10. Baker J. U.S. Foreign Policy Priorities and Fiscal Year 1991 Budget Request. Statement by Secretary of State. 1 Febr. 1990 // American Foreign Policy. Current Documents. 1990. U.S. Department of State. Wash., 1991. P. 5.

11. Белевцева С.Н. Силовое продвижение американской демократии в регионы мира в период первого президентского срока Билла Клинтона // Ученые записки. Электронный научный журнал Курского государственного университета. 2018. № 3 (47). C. $68-82$.

12. Renewing American Civilization (House of Representatives - January 25, 1993) // Congressional Record 103rd. H. 197.

13. Клинтон У.Дж. Моя жизнь. М.: Альпина Бизнес Букс, 2005. 1088 с.

14. Inaugural Address. 20.01.1989 [El. resourse] // Public Papers. George Bush Presidential Library and Museum. - https://bush41library.tamu.edu/archives/publicpapers/1.

15. Statement at Senate Confirmation Hearing. Secretary-Designate Christopher. Statement before the Sen- ate Foreign Relations Committee, Washington, DC, January 13, 1993 // US Department of State Dispatch. Bureau of Public Affairs. January 25, 1993. Wash., DC: US GPO. Vol. 4, № 4. P. 46.

16. Престовиц К. Страна-изгой. Односторонняя полнота Америки и крах благих намерений. СПб.: Амфора. ТИД Амфора, 2005. 606 c.

17. Стратегия национальной безопасности США. Стратегия вовлеченности в международные дела и распространение демократии в мире // США - Канада: экономика, политика, идеология. 1994. №№ 11, 12; 1995. №oo $1,2$.

18. Стратегия национальной безопасности США. Стратегия вовлеченности в международные дела и распространение демократии в мире (окончание) // США - Канада: экономика, политика, идеология. 1995. № 2. C. 112-126.

19. National Security Strategy of the United States. The White House, Washington, DC, 1991. P. 25.

20. Кузнецов Д.В. Американское общественное мнение и использование военной силы: Период президентства Уильяма Дж. Клинтона (1993-2001 гг.). М.: Книжный дом «ЛИБРОКОМ», 2011.304 c.

21. Remarks at the United States Military Academy in West Point, New York. 05.01.1993 // Public Papers. George Bush Presidential Library and Museum. https://bush41library.tamu.edu/archives/publicpapers $/ 5156$

\title{
«DEMOCRACY DISTRIBUTION» STRATEGY AS A MECHANISM FOR U.S. FOREIGN POLICY GOALS ACHIEVING (LATE 1980S - FIRST HALF OF THE 1990S)
}

(C) 2019

Belevtseva Svetlana Nikolaevna, candidate of historical sciences, associate professor of World History Department Kursk State University (Kursk, Russian Federation)

Abstract. The paper deals with the US foreign policy during the presidency of George W. Bush and B. Clinton's first presidential term. The author analyzes practical steps of the American administration related to the use of «democracy distribution» strategy as one of the main tools of the American foreign policy. The paper traces the use of «democracy distribution» strategy for the purpose of American global leadership achieving in the conditions of the unipolar world. The author also shows the influence on the US foreign policy precedent creation - lack of deterrent in the face of the USSR. Special attention is paid to the promotion of American-style democracy to the regions of the world where conflict situations arose. The paper also contains the facts that the American establishment justified the necessity of American leadership in international affairs as well as the assessments of the US foreign policy of power pressure under the slogan of «democracy distribution». The paper is based on the documentary materials of the US presidents G.W. Bush and B. Clinton, as well as documents of the U.S. Department of state and Congress. The views of prominent American political scientist Henry Kissinger, President of the American economic strategy Institute Clyde Prestowitz and Russian historian Vladimir Sogrin are used to assess the activities of the American administrations.

Keywords: «democracy distribution» strategy; American global leadership; regional conflicts; policy of power pressure; USSR as deterrent; continuity of American foreign policy; need for changes in American foreign policy; inconsistency of ideas and practices of US foreign policy.

УДК 93/94

DOI 10.24411/2309-4370-2019-11215

Статья поступила в редакцию 11.01.2019

\section{ЯПОНСКАЯ КОЛЛЕКЦИЯ В.В. ВЕРЕЩАГИНА: ВОПРОСЫ, ОТВЕТЫ, ЗАГАДКИ}

(C) 2019

Кацнельсон Галина Сергеевна, кандидат исторических наук, преподаватель лицея Национальный исследовательский университет «Высшая школа экономики» (г. Москва, Российская Федерация)

Аннотащия. В данной статье рассматривается коллекция японских произведений искусства, которые были приобретены известным российским художником В.В. Верещагиным в ходе его путешествия в Японию в 1903 г. В статье представлена основная информация о самом путешествии, приводятся выдержки из заметок Верещагина о стране и интересующих его произведениях искусства, которые он покупал. Описание коллек- 
ции, собранной Верещагиным, осуществляется на основании мемуаров сына Верещагина, а также «Каталога выставки картин и рисунков покойного художника В.В. Верещагина и собранной им коллекции японских предметов (принадлежащих вдове его Л.В. Верещагиной)». Каталог был выпущен для выставки-продажи в галерее Лемерсье в Москве в 1910 г. Раздел каталога, посвященный японской коллекции, охватывает перечень №№ 76-355. Среди данных артефактов выделяются группы: предметы интерьера, текстиль и предметы из ткани, одежда и аксессуары, эмаль, бронза, черепаха, дерево, фарфор и фаянс, а также разнообразные мелочи. В соответствии с данными группами осуществляется описание коллекции. В статье высказываются предположения о причинах продажи коллекции и её дальнейшей судьбе после выставки-продажи. Изучение предметов, привезенных Верещагиным из Японии, позволяет понять, что интересовало художника в японской жизни и быте.

Ключевые слова: В.В. Верещагин; японское искусство; коллекционирование; коллекционер; частные коллекции; восточное искусство; восточная коллекция; японская коллекция; ориенталист; художник; коллекционеры Москвы; коллекционирование в России; российские художники; российские коллекционеры; ориентализм; востоковедение.

В.В. Верещагин - известный российский художник, путешественник, коллекционер. Посещение Японии стало последней заграничной поездкой Василия Васильевича перед его гибелью на русскояпонской войне. Верещагин отправился в Японию, будучи опытным путешественником (к этому времени он объездил Среднюю Азию, Туркестан, Кавказ, Русский Север, Европу, Индию, Филиппины, США, Кубу), художником, которого хорошо знали в России и за границей, и многое пережившим человеком (в 1903 г. ему исполнился 61 год) [1, с. 268-279].

Где бы Верещагин ни путешествовал, из всех поездок он привозил этнографические коллекции, в которые входили оружие, посуда, одежда, украшения, декоративно-прикладное искусство, предметы быта и культа [2, с. 93]. Вещи он использовал при написании картин и для оригинального декорирования своих выставок. Предметы, привезенные художником, размещались вместе с картинами в выставочных залах, что позволяло зрителям лучше погрузиться в атмосферу изображенных мест, также на выставках специально применялось искусственное художественно распределенное освещение [3, с. 6]. Для создания среди посетителей настроения, соответствующего содержанию картин, и для усиления впечатления от них на некоторых выставках небольшой оркестр или фисгармония исполняли русские музыкальные сочинения. По отзывам зрителей, внешняя обстановка экспозиций верещагинских работ неизменно поражала эффектностью [4, с. 144].

Можно с уверенностью утверждать, что наряду с живописью и путешествиями коллекционирование было третьим главным жизненным делом Верещагина, что позволяет считать его одним из представителей сообщества российских коллекционеров [5, c. 86]. Необходимо отметить, что в России конца XIX - начала XX вв. существовал интерес к восточному искусству в целом и к японскому в частности. Сложилось неформальное сообщество коллекционеров, представители которого были из разных социальных и профессиональных слоев общества. Коллекции произведений японского искусства собирали морские офицеры, плававшие на военных кораблях в дальневосточных морях. Среди офицеров, которые передали собранные ими коллекции в Кунсткамеру, необходимо упомянуть А.Е. Кроуна, В.В. Линдстрема, К.Н. Посьета [6, с. 76] Крупнейшим коллекционером японского искусства, иллюстрированных ксилографических книг, вспомогательных материалов (фотографии и издания по искусству) был морской офицер С.Н. Китаев, который организовал три выставки своей коллекции в 1896 г. (Санкт-Петербург), 1897 г. (Москва), 1905 г. (Санкт-Петербург). В настоящее время его коллекция находится в ГМИИ им. А.С. Пушкина [7, с. 19]. Японскую гравюру собирали художники и любители искусства И.Э. Грабарь, С.А. Щербатов, А.Н. Бенуа, Д.И. Митрохин, В.В. Горшанов и многие другие [8, с. 609]. Коллекционированием японского искусства занимались купцы и предприниматели П.И. Щукин, Д.Г. Бурылин, К.С. Попов, И.С. Остроухов [9, с. 8-9].

Верещагин также собрал интересную коллекцию предметов японского искусства. Прежде чем перейти непосредственно к японской коллекции, необходимо вспомнить основные сведения о поездке В.В. Верещагина в Японию. Художник отправился в Японию в августе 1903 года. Ему предстоял долгий путь: сначала на поезде из Москвы во Владивосток (более недели), а затем двое суток на пароходе через Японское море. Пароход привез художника в Цуругу (остров Хонсю) [10, с. 338, 341-342]. Верещагин понимал, что для свободного перемещения и работы в стране, неизбежная война с которой была всего лишь вопросом времени, ему понадобится помощь и покровительство официальных лиц. Он рассчитывал на содействие русского посланника в Японии Ф.Ф. Розена, с которым познакомился в США. Поэтому из Цуруги он отправился к Розену в Токио, но не застал, поскольку посланник находился в Никко. Верещагин поспешил туда, но опоздал, Розен вернулся в столицу [10, с. 341-343]. Наконец он встретился с Розеном в Токио. Ф.Ф. Розен обещал поддержку и познакомил художника с обер-церемонимейстером двора - бароном Санномия, известным своей приверженностью европейским обычаям и взглядам. Барон дал Верещагину в сопровождающие своего чиновника с письмом к главным священнослужителям Никко (поскольку художник намеревался работать именно там) - буддийскому и синтоистскому, чтобы они разрешили рисовать священные сооружения [10, с. 346].

Художник писал заметки о своих впечатлениях о Японии, которые публиковались в газетах. Среди его описаний городов и быта японцев есть упоминание о посещении токийских лавок и об интересующих его вещах: «Мне были очень интересны лавки их старьевщиков, с разными безделушками из посуды, статуэток, ваз, блюд, всякого рода ящиков, посуды... трудно передать прелесть этого товара в том случае, когда он произведен хорошими мастерами, преимущественно старыми, и оригинален, т.е. неподделен» [11, с. 139]. Художник восхищался нэцкэ - «попадаются прямо шедевры резьбы»; шелковыми кимоно - 
«цвета до того хороши», «куплю целую серию этих одежд»; также внимание его привлекли ткани и изделия из них - «очень хороши бумажные материи набивки всевозможных, часто очень пестрых узоров и преоригинальных рисунков», «парчи очень хороши»; «шитье шелками для подушек, покрывал к кроватям, для подвесок на стены, также для ширм, очень хорошо и недорого» $[11$, с. 139-140]. Верещагин с гордостью пишет, что ему удавалось успешно торговаться и добиться уступок в лавках Токио, но уточняет, что главные покупки он отложил до Киото, «где по сведениям было дешевле, чем в Токио» $[11$, c. 141]. Приближающаяся война помешала пребыванию художника в Японии. Был объявлен последний рейс парохода во Владивосток, с ним В.В. Верещагин покинул страну, чтобы не остаться на положении интернированного. Домой художник возвращался морским путем: из Владивостока через Сингапур, Суэцкий канал и Босфор. Верещагин прибыл в Москву в конце ноября 1903 г. после трехмесячного пребывания в Японии [10, с. 349].

Что же представляла собой японская коллекция Верещагина? Сын художника оставил мемуары, в которых написал о богатом багаже, который прибыл с отцом из Японии: «Здесь были старинный и новый фарфор, бронза, по большей части старинная, множество художественно исполненных фигурок людей, животных, птиц, вырезанных из слоновой кости, черного и орехового дерева - так называемые нэцкэ, красиво расписанные деревянные лакированные коробки, шелковые и бумажные, пропитанные какимто составом зонтики, различных размеров фонарики из полупрозрачной шелковой бумаги, веера с резными ручками слоновой кости или черного дерева, парадные, расшитые шелками кимоно, парики японских гейш, пояса. Матери особенно нравились вышитые шелками панно с традиционными изображениями цветущей вишни, хризантем, священной горы Фудзияма. Панно были обрамлены полосами золотистой парчи, а изображения на них исполнены с таким совершенством, что создавали скорее впечатление живописи, нежели вышивки» [4, с. 116-117]. Далее сын художника вспоминает старинное ручное металлическое зеркало в виде круга и большой трехпудовый камень-скалу, какие имеются в японских садиках. На камне были растения и карликовые сосенки, но они погибли в дороге, и решено было оставить его для украшения интерьера, поместив на деревянной колонне в мастерской [4, с. 116-117]. По утверждению сына, ряд предметов японской коллекции отца (камень-скала, панно, фонарики, вазочки, резной столик орехового дерева со стоящей на нем бронзовой лилией» видны на фотографиях мастерской, сделанных в 1904 г. перед посмертной выставкой отца [4, с. 116-117].

Есть еще одно упоминание японских предметов верещагинской коллекции, сделанное В.А. Сизовым из «Русских Ведомостей». Согласно ему, японские предметы украшали интерьер мастерской художника в Нижних Котлах: на стене на ветвистых оленьих рогах были развешаны красивые японские фонари, на полке были расставлены предметы японской индустрии наряду с индийскими и китайскими, а спальня Верещагина была украшена превосходными японскими панно с изображениями крупных водяных птиц [3, с. 114-115].
Вернувшись из последнего путешествия, Верещагин принялся за работу над серией картин на японские темы, но завершить ее не успел, поскольку в феврале 1904 г. началась русско-японская война, художник отправился на театр военных действий, где погиб в Порт-Артуре 31 марта 1904 г. при взрыве броненосца «Петропавловск». Имущество художника (в том числе этнографические коллекции) унаследовала его семья - жена Лидия Васильевна и трое несовершеннолетних детей. Поскольку после гибели художника о его японской коллекции долго не было известно, уместно будет обратиться к обстоятельствам жизни семьи Верещагина.

По словам сына, их семья осталась после смерти Василия Васильевича в очень стесненных обстоятельствах. Путешествия, которые совершал Верещагин, требовали больших расходов, ему приходилось много занимать и влезать в долги. Художник получал большие деньги за серии картин, но в силу непрактичного характера не делал сбережений: «Получив большую сумму и расплатившись с долгами, если таковые в то время были (а это случалось часто!), он оставлял себе лишь такую ее часть, которая, по его предположению, была необходима на расходы в ближайшем будущем. Остальные деньги он считал свободными и не использовал их для накопления материальных благ или создания резервного капитала, а употреблял главным образом на пожертвования, преимущественно на школы» [4, с. 141]. П.В. Андреевский (младший брат Л. Верещагиной), который близко общался с художником и жил в семье сестры в студенческие годы в своих воспоминаниях также свидетельствует о нестабильном материальном положении Верещагина: «После его смерти никакого капитала не осталось, если не считать двух-трех тысяч... Многие считали его очень богатым человеком - это неверно. Несмотря на то, что он получал очень крупные суммы за свои картины, которые ценились дорого, у него никогда не накапливались деньги в банке... Получив 100-150 тысяч, он был вынужден на них жить чуть ли не десять лет до следующей серии... Кроме того, он делал немало пожертвований, доходивших после больших получек до десятка тысяч» $[12$, с. 147].

Художник оставил завещание, в котором были даны подробные указания о том, как необходимо поступить с имуществом и картинами. Согласно его воле, после его смерти должна была состояться выставка картин, по окончании которой картины следовало продать на аукционе, деньги, вырученные от продажи, положить в банк, выплатив предварительно долги. Семья должна была жить на проценты, получаемые с капитала [13, с. 319].

Посмертная выставка картин и этюдов Верещагина, по окончании которой предполагался аукцион, состоялась через несколько месяцев после гибели художника. Выставка проходила 15 ноября - 12 декабря 1904 г. в Санкт-Петербурге в помещении Общества поощрения художников. К выставке был выпущен каталог с предисловием, которое написал В.В. Стасов - критик и давний друг Верещагина. Однако в каталоге выставки перечислены только картины масляными красками, фотографии и рисунки, японские предметы не указаны [14]. Сын художника в воспоминаниях написал, что на выставке были представлены вещи отца - письменный стол, индий- 
ские ковры, коллекция восточного и иного оружия и артефакты времен русско-турецкой войны 1877 1878 гг. [4, с. 131-132]. О японских предметах он не упомянул. Но на фотографии с посмертной выставки можно разглядеть наряду с предметами, упомянутыми Верещагиным-младшим, вазы и мелкие предметы декоративно-прикладного искусства, которые вполне могут быть из японского собрания художника [15]. Возможно, что они тоже использовались для декорирования помещения, но сын забыл или не счел нужным об этом написать.

Аукцион картин и этюдов Верещагина не состоялся, поскольку вся выставка была куплена правительством. В разных работах, посвященных жизни и творчеству Верещагина, подробно излагается история этого приобретения. Академик М.П. Боткин по просьбе Л.В. Верещагиной оценил выставку и назвал сумму более чем в 150 тысяч рублей. Однако в художественных кругах ходили разговоры о баснословных суммах (до миллиона рублей), которые должна была получить вдова, поскольку только за отдельные картины предлагались десятки тысяч рублей. В преддверии аукциона в Петербург съезжались коллекционеры, в том числе иностранцы, желающих купить картины было много. Но Л.В. Верещагина, совершенно не заботясь о материальной выгоде, боролась за то, чтобы картины покойного супруга остались в России, как того хотел сам Верещагин. Она вела переписку с министром двора В.Б. Фредериксом по поводу приобретения картин правительством, в которой соглашалась принять любую сумму, которую ей назначат. Наконец царское правительство купило выставку за сто тысяч рублей [13, c. 290]. Картины В.В. Верещагина поступили в Русский музей [10, с. 367-370].

Л.В. Верещагина, получив сто тысяч рублей от правительства, уплатила из этой суммы деньги за организацию посмертной выставки и долги. Оставшаяся сумма была, по воспоминаниям сына, незначительна, хотя семье предстояли большие расходы. Все трое детей были несовершеннолетними, кроме того, по завещанию В.В. Верещагина его семья должна была посылать 1000 рублей в год первой супруге художника Е.К. Верещагиной-Фишер, проживавшей в Мюнхене [13, с. 319]. Лидия Васильевна была вынуждена хлопотать о пенсии для детей. Сначала император Николай Второй назначил ей пенсию в размере 2400 тысяч в год, затем сократил эту сумму до 1000 рублей. Одним из мотивов снижения было соображение, что нельзя семье Верещагина назначать большую пенсию, чем пенсию, которую получала семья художника М.О. Микешина [13, с. 347].

Как указывалось выше, японская коллекция хранилась в доме Верещагиных (деревня Нижние Котлы). Вдова художника предлагала дом в дар московским городским властям, в качестве мемориала, но власти отказались, также она пыталась передать личные вещи мужа и обстановку его мастерской Русскому музею, но также получила отказ. В конце концов дом был продан на строительный материал фабриканту К.К. Веберу, а вдова переехала с детьми в город в съемную квартиру, вероятно, что вещи, привезенные из Японии, хранились в семье [10, с. 370-372].

Деятельность Л.В. Верещагиной по увековечению памяти о муже вызывает уважение и восхищение. Однако возникает вопрос, если семья осталась в тяжелом материальном положении, почему вдова готова была отдать дом (на деньги от продажи которого можно было жить) даром? Ответ очевиден: условия жизни семьи стали отличаться от привычных для них, но о нищете речь, разумеется, не шла. У семьи было имение на Кавказе, на доходы от которого можно было жить и которое художник Верещагин также упомянул в завещании [13, с. 319].

Вернемся к японской коллекции художника. Полное представление о ней можно получить из каталога, который называется «Каталог выставки картин и рисунков покойного художника В.В. Верещагина и собранной им коллекции японских предметов (принадлежащих вдове его Л.В. Верещагиной)». Каталог был выпущен для выставки-продажи в галерее К. Лемерсье по адресу: Москва, Петровка, Салтыковский переулок, 8. Согласно каталогу, на продажу выставлялись 27 картин, 75 рисунков и коллекция японских предметов. Примечательно, что в Российской государственной библиотеке, где имеется экземпляр каталога, в его библиографическом описании в картотеке алфавитного каталога не указан год издания. На самом каталоге год и место издания также отсутствуют. Однако данная выставка-продажа указана в списке выставок художника, который приводится в книге Лебедева А.К. Верещяагин $u$ В.В. Стасов: с приложением переписки В.В. Верещагина и В.В. Стасова за 1885-1904 г2. Согласно книге, выставка в галерее Лемерсье проходила осенью 1910 г. [16, с. 235]. Таким образом, через шесть лет после гибели Верещагина вещи, привезенные им из Японии, были выставлены на продажу.

Раздел каталога, посвященный коллекции японских предметов, охватывает предметы №№ 76-355 [17]. Перечень предметов, привезенных Верещагиным из Японии, позволяет понять, что интересовало художника в японской жизни и быте.

Прежде всего внимание привлекают предметы интерьера. Список начинается с японских ширм, которые являются самыми дорогими вещами коллекции - 700 рублей. Далее указаны экран, шитый шелком и с живописью (150 рублей), столик резной (80 рублей) и несколько панно: петухи (500 рублей), павлин (600 рублей), лотосы (400 рублей), чайки над морем (600 рублей), чайки над водопадом (500 рублей), ночь (200 рублей), журавли (2 панно по 100 рублей каждое). К данной группе можно отнести также ковер, 5 циновок, 6 стор, фонари (1 на подставке и 5 бумажных) и 3 метлы.

Следующая группа - текстиль и предметь из ткани: покрывала из храма (2 шт.), салфетки (1 для стола и 12 маленьких), полотенца (8 шт.), вышивки (8 шт.). Обращает внимание большое количество тканей - 61 шт., причем помимо шелка, который обычно везли из Японии, представлен ситец, бумажная материя и шерсть. Мы помним, что в своих японских записках Верещагин с восхищением писал об узорах и рисунках на тканях; по-видимому, находясь под сильным впечатлением от них, он и совершил столь крупные покупки. Художника вероятно интересовало декоративно-прикладное искусство Японии, чем объясняется и наличие в коллекции 8 образцов японской резьбы.

Список содержит много предметов одежды пояса (10 шт.), причем не указано, мужские они или женские, шарфики (5 шт.), шляпы (2 шт.), головной 
убор, халаты (40 шт.) - возможно, так назвали кимоно, чулки (3 п.), башмаки (3 п.), сандалии (1 п.), брюки (1 п.). Наряду с одеждой в каталоге представлены и аксессуары: разнообразные веера (25 шт.) - деревянные, вышитые, складные, простые и круглые с живописью; зонтики (6 шт.), сумки с пуговицами из слоновой кости (2 шт.).

По-видимому, Верещагин видел выступления артистов и заинтересовался театром и музыкой японцев, поскольку в его коллекции присутствует парик (но не указано, мужской или женский), маски (5 шт.) и японский музыкальный инструмент (к сожалению, также не указано, какой именно, но возможно, что это была флейта, изображенная на одной из его «японских» картин).

В данном разделе каталога представлены разнообразные мелочи: зеркало металлическое с фокусом, о нем упоминал сын художника в мемуарах, cachepot, блюдечко, зубочистки, вязальный крючок, птица (не указано, какой птицы чучело), японец деревянный, 4 книги (вероятно, об искусстве, но не указано, на каком языке), календарь, 33 открытки, 161 картинка, 91 фотография, а также картины: 6 картин на материи по 75 коп. и «32 картины старинные в свёртках» (вероятно, что имеются в виду картины в свитках, их цена в каталоге не указана). По поводу последних возникает вопрос, что это были за картины и почему, если они были действительно старинными, то указаны без цены?

Далее идет раздел - эмаль (№ 190-210). Самые дорогие предметы раздела - чашки эмалевые китайские желтая и синяя по 100 и 60 руб. соответственно, лилия железная с эмалевой крышкой - 50 руб. В разделе также представлены вазы, чашки, чайники, тарелка и блюдечко, старинный эмалевый сосуд с крышкой, эмалевая коробка с резной крышкой, пепельницы, пряжки, песочница, чернильница.

Следующий раздел - бронза (№ 211-249). Самым дорогим предметом является большая ваза с драконом - 75 руб. и бронзовый фонарь с шелком - 50 руб. В перечне присутствуют другие вазы (но гораздо более дешевые), маленькие вазочки, чашки, чайники, подсвечники, курительницы, песочница, пудреница, чернильница, фонарь, нож. Вероятно, художника заинтересовала бронзовая скульптура, о чем свидетельствуют наличие нескольких экспонатов: журавль на черепахе, лягушка, краб, рак. В этом разделе указаны и нэцкэ, в перечне их 7 (дракон, рыба, борьба с обезьяной и непонятно описанные).

В разделе черепаха (№ 250-271) указаны 16 шпилек, 2 гребня, 2 блюда, нож примечателен тем, что в нем вообще отсутствуют цены на предметы.

В разделе дерево (№ 272-329) самым дорогим предметом является ящик лакированный с бронзой 25 руб. и ящик из железного дерева с золотом 15 руб. В разделе представлены и другие ящики (перчаточный и ящик с малым ящиком внутри), коробки и коробочки, подносы из железного дерева, лакированные подносы, блюдо, резные тарелки, корзинки, чашки лакированные; подносики, разные мелочи - тарелка, ложка, гребенка, тыква, подставки под вазы.

Последним разделом является фарфор и фаянс (№ 330-355). В этом разделе представлены предметы знаменитого сацумского фарфора. Этот фарфор ценился в самой Японии. Не случайно, когда Николай
Второй, будучи царевичем, посетил Японию в ходе своего путешествия на Восток в 1890-1891 гг., среди многочисленных подарков, которые ему подносились, были сацумские вазы, в декор которых была включена монограмма «Н» [18, с. 138]. Сацумский фарфор пользовался большим спросом на Западе, его образцы охотно приобретали путешественники и коллекционеры, Верещагин, вероятно, знал об этом и сделал аналогичные покупки.

Самый дорогой предмет среди данного раздела каталога - ваза (40 руб.). Также представлены более дешевые вазы сацума, курительницы, чайный сервиз, чашки сацума с блюдечком, чашка сацума туалетная и множество других чашек.

Даже беглый просмотр каталога позволяет увидеть, что Верещагина глубоко заинтересовал быт японцев, их национальный костюм, предметы интерьера, посуда, национальные промыслы, декоративно-прикладное искусство. Вероятно, что у него были разнообразные творческие замыслы картин, на которых можно было изобразить привезенные предметы.

Однако коллекция оставляет и вопросы. Прежде всего, почему она не выставлялась на продажу раньше? Вероятно, это связано, во-первых, с русскояпонской войной, во время которой естественным было неприязненное отношение к Японии, и для семьи художника, погибшего на войне, выставлять на продажу данные предметы было бы неэтично. Вовторых, эта коллекция была последним приобретением Верещагина в его последнем путешествии перед гибелью, и Л.В. Верещагина, горячо любившая мужа, не хотела расставаться с этими вещами.

Почему же в 1910 году она выставила коллекцию на продажу? Известно, что Лидия Васильевна ненадолго пережила супруга. У нее обнаружили рак, болезнь прогрессировала, надежды на выздоровление не было. В 1911 г. она покончила с собой в частной клинике, где проходила лечение [13, с. 347]. Вполне возможно, что за год до ее гибели деньги от продажи коллекции требовались на лечение и образование подросших детей. Но тогда возникает другой вопрос: почему на продажу были выставлены не только дорогие вещи, продажа которых принесла бы большие суммы, но и открытки, картинки и всевозможные мелочи, цена которых - 10, 25 коп., 75 коп., максимум рубль-полтора или которые вообще указаны без цены, как вещи из раздела «черепаха»? Продажа этих вещей не принесла бы большой прибыли, но их вполне можно было бы оставить в качестве памяти об отце. Подобная распродажа устраивается, если семье грозит нищета и каждая копейка на счету или когда вещи совершенно не нужны владельцу по какой-либо причине. Поскольку нет сведений о бедственном положении семьи Верещагина в этот период, а, наоборот, есть данные, что семья продолжала посылать деньги бывшей жене Верещагина, то первая версия отпадает [13, с. 347]. Вероятнее всего, что Лидия Васильевна была в этот период времени в тяжелом эмоциональном состоянии, она болела, страдала, предчувствовала свой уход из жизни и решила избавиться от всех вещей сразу.

Очень грустно это констатировать, но всё, что с азартом, интересом и любовью покупал художник Верещагин в Японии, с течением времени стало никому не нужно, в том числе и самым близким для него людям. 
Содержание коллекции также вызывает вопросы. Почему в ней не представлено оружие, кроме двух ножей - бронзового и с черепаховой рукоятью? Верещагин интересовался оружием, разбирался в нем, привозил из разных поездок, неужели его ставили равнодушным самурайские мечи, луки, панцири, шлемы? Почему он не приобрел набора для каллиграфии? Почему в коллекции отсутствуют любые предметы, связанные с духовной жизнью и верованиями японцев (кроме храмовых покрывал и курительниц) - изображения Будды, Дарумы, Дзидзо, лисьего бога Инари, тануки? Ведь Верещагиным была задумана целая серия картин, посвященных Японии, и ему могли понадобиться разные предметы.

Вероятно, что так и останется неустановленным, кто купил вещи из японской коллекции Верещагина. Как указывалось выше, в России были крупные коллекционеры, которых могли заинтересовать предметы японского искусства. Попало ли что-то из собрания Верещагина в другие коллекции или в музеи? Другой вопрос, могли ли заинтересовать крупных коллекционеров предметы из верещагинской коллекции? Если бы кто-то хотел купить те же самые «картины старинные в свёртках», вероятно, что они бы не были выставлены, их купили бы раньше. Возможно, что коллекция просто разошлась по рукам любителей экзотики, желавших украсить дома красивыми вещами.

Возможно, что какие-то японские предметы верещагинского собрания попали на территорию современной Украины. Дело в том, что в 1914 году в г. Николаеве членами местного общества любителей изящных искусств был основан Художественный музей, которому было присвоено имя Верещагина. Большую помощь обществу оказал И.Е. Репин. Как указано на сайте музея, его открытие состоялось 6 июня 1914 года - в этом году было 10-летие трагической гибели на броненосце «Петропавловск» вицеадмирала С.О. Макарова и художника-баталиста В.В. Верещагина. Необходимо отметить, что Николаев - родной город адмирала С.О. Макарова. Основу музейной экспозиции составили 148 произведений В.В. Верещагина (картин, этюдов и рисунков), которые были получены из Русского музея императора Александра III. На открытии музея среди самых почетных гостей был сын В.В. Верещагина [19]. Семья художника подарила музею его личные вещи, среди которых вполне могли быть предметы из японской коллекции, не проданные в 1910 г. и остававшиеся в семье [20, с. 18]. Однако ни в путеводителе по музею, ни на сайте не указано, какие именно вещи Верещагина попали в Николаев. У музея была сложная судьба, в годы Великой Отечественной войны он оказался в оккупации и был разграблен [20, c. 18]. В послевоенное время музей был восстановлен, но чтобы узнать, какие вещи были переданы туда семьей, что уцелело во время оккупации, что находится в музее в настоящее время, необходимо обратиться непосредственно в музей.

Судьба японской коллекции В.В. Верещагина один из многочисленных сюжетов, связанных с темой коллекционирования японского искусства в России. Ее изучение (пусть даже по скудным источникам) и сопоставление с другими коллекциями позволяет понять отношение Верещагина к Японии и японцам, сущность его интереса к культуре данной страны.

\section{Список литературы:}

1. Недаром помнит вся Россия: мат-лы междунар. конф., посв. 160-летию В.В. Верещагина и 190-летию Бородинского сражения. Череповец, 2003. 284 с.

2. Полунина Н., Фролов А. Коллекционеры старой Москвы: биографический словарь. М.: Независимая газета, 1997. 528 с.

3. Булгаков Ф.И. В.В. Верещагин и его произведения. СПб.: Типография А.С. Суворина, 1905. 197 с.

4. Верещагин В.В. Воспоминания сына художника. Л.: Художник РСФСР, 1982. 183 с.

5. Банников А.П., Сапожников С.А. Собиратели и хранители прекрасного: энциклопедический словарь российских коллекционеров от Петра Первого до Николая Второго 1700-1918 гг. М.: Центрполиграф, 2007. $607 \mathrm{c}$.

6. Кисляков В.Н. Российские морские офицеры собиратели коллекций МАЭ (Китай, Корея, Япония) // Кюнеровские чтения (2001-2004): краткое содержание докладов. СПб.: МАЭ РАН, 2005. 212 с.

7. Штейнер Е.С. Коллекция японского искусства Китаева: сто лет назад и сейчас // Исторический журнал: научные исследования. 2011. № 2 (2). С. 19-32.

8. Воронова Б.Г. О раннем этапе собирания и изучения японского искусства в России // Введение в храм: сб. ст. М.: Языки русской культуры, 1998. 800 с.

9. Каневская Н.А. Японская миниатюрная скульптура нэцкэ в собрании Государственного музея Востока. Каталог коллекции. М.: ГМВ, 2018. 240 с.

10. Дёмин Л.М. С мольбертом по земному шару: мир глазами В.В. Верещагина. М.: Мысль, 1991. 373 с.

11. Верещагин о зарубежном Востоке. М.: Издательство РУДН, 2001. 175 с.

12. Андреевский П.В. Воспоминания о В.В. Верещагине // Панорама искусств 8. М.: Советский художник, 1985. С. 122-151.

13. Лебедев А.К. Василий Васильевич Верещагин. Жизнь и творчество: 1842-1904. М.: Искусство, 1972. 395 c.

14. Каталог посмертной выставки картин и этюдов В.В. Верещагина. СПб.: Имп. О-во поощрения художеств, 1904. $32 \mathrm{c}$.

15. Японский мир Василия Верещагина [Электронный ресурс] // https://artchive.ru/publications/3414 japonskij_mir_vasilija_vereschagina.

16. Лебедев А.К. В.В. Верещагин и В.В. Стасов: с приложением переписки В.В. Верещагина и В.В. Стасова за 1885-1904 гг. М.: Искусство, 1953. 236 с.

17. Каталог выставки картин и рисунков покойного художника В.В. Верещагина и собранной им коллекции японских предметов (принадлежащих вдове его Л.В. Верещагиной) // Галерея Лемерсье. М., 1911. 24 c.

18. Успенский М.В. Из истории японского искусства: сб. ст. СПб.: Изд-во Государственного Эрмитажа, 2004. 152 c.

19. Николаевский областной художественный музей имени В.В. Верещагина [Электронный ресурс] // http://vereschagin.com.ua/ru/o-muzee/istoriya-muzeya.html.

20. Николаевский художественный музей имени В.В. Верещагина: путеводитель. Одесса: Маяк, 1986. $48 \mathrm{c}$.

Статья публикуется при поддержке гранта Японского фонда.

Самарский научный вестник. 2019. Т. 8, № 1 (26) 


\section{JAPANESE COLLECTION OF V.V. VERESHCHAGIN: QUESTIONS, ANSWERS, SECRETS}

(C) 2019

Katsnelson Galina Sergeevna, candidate of historical sciences, teacher of Lyceum National Research University «Higher School of Economics» (Moscow, Russian Federation)

Abstract. The paper is dedicated to the collection of Japanese art objects, which were bought by the famous Russian artist V.V. Vereshchagin during his travelling to Japan in 1903. The paper represents the main information about the travel and excerpts from Vereshchagin's memories about the country and art objects he bought. The description of the Vereshchagin's collection was made on the base of the memories of Vereshchagin's son and the catalogue of the collection which was published for the trade-exhibition in Moscow in 1910. Japanese collection's part of the catalogue consists of the objects № 76-355. Some groups were distinguished among those artifacts: interior items, textile, clothes, accessories, enamel, bronze, turtle, porcelain, faience and different trivia. The description of the collection was made in connection with those groups. Some thoughts are represented about the main reasons of the collection's trade-exhibition and its fate after the trade-exhibition. Analyzing the art objects, which were brought by Vereshchagin from Japan could help to understand what artist's interest was in Japanese life.

Keywords: V.V. Vereshchagin; Japanese art; collecting; collector; private collections; Oriental art; Oriental collection; Japanese collection; orientalist; painter; collectors of Moscow; collecting in Russia; Russian artists; Russian collectors; Orientalism; Oriental studies.

УДК 94 (73)

DOI 10.24411/2309-4370-2019-11216

Статья поступила в редакцию 08.01.2019

\section{ВОЙНА, ИМПЕРИАЛИЗМ И КОЛОНИИ: ОЦЕНКИ АМЕРИКАНСКОЙ ПРЕССЫ}

(C) 2019

Буранок Сергей Олегович, доктор исторических наук, профессор кафедры всеобщей истории, права и методики обучения

Самарский государственный социильно-педагогический университет (г. Самара, Российская Федерация)

Аннотация. Вопросы о перспективах колониальной системы европейских империй после Великой войны, формах и путях её перехода в постколониальный век, а также относительности опыта колониальных держав к внешней политике США были очень популярны и довольно спорны для американского общественного мнения во время и после окончания Первой мировой войны. Исследование колониальной системы не может быть полным без изучения прессы держав, подписавших Версальский договор. Для того чтобы дать подробный анализ международных отношений с точки зрения глобальных преобразований с американской точки зрения, необходимо проанализировать соответствующие газетные статьи, опубликованные после Великой войны. Результаты показали изменение приоритета в американском публичном дискурсе в 1919-1922 гг. в схемах трансформации колониальной системы. План Вудро Вильсона по демонтажу колониальных держав постепенно заменялся менее радикальными планами, которые предполагали использование колониального опыта во внешней политике США. Материалы американской прессы за 1919-1922 гг. показывают, что был поиск наиболее эффективной и оптимальной стратегии отношений не только с европейскими империями, но и с зависимыми от них территориями. Анализ американской прессы показывает её постоянный интерес к негативному и позитивному опыту колониальных империй в поисках «уроков истории». В 1919-1922 годах наиболее выдающиеся журналисты были сосредоточены на Европе, которая была представлена Белым домом, Государственным департаментом США и средствами массовой информации в качестве краеугольного камня внешней политики США. И мы можем ясно видеть другой фактор, влияющий на подходы к колониальной проблеме в американской прессе. Это была внимание Советской России и поддержка национальноосвободительных движений в Азии и Африке. «Красная угроза» стала одним из факторов, заставивших американские СМИ пересмотреть колониальную проблему в свете нового мирового порядка, который был создан после окончания Великой войны на базе Версальского соглашения.

Ключевые слова: Версальский договор; Первая мировая война; колониализм; США; американская пресса; общественное мнение США; антиимпериализм; Версальско-Вашингтонская система; колониальные империи; Британская империя; В. Вильсон; внешняя политика США; американо-японские отношения; англоамериканские отношения.

Вопросы о перспективах колониальной системы, о переходе в переходную эпоху от колониализма к постколониализму, о вероятности использования опыта европейских империй являлись весьма актуальными и острыми в обществе США ХX века [1]. Ocoбо ожесточённая дискуссия развернулась после Первой мировой войны (1918-1922) [2]. Анализ американской прессы будет способствовать выявлению обсуждаемых в тот период моделей решения колониального вопроса. Кроме того, обращение к прессе

позволит более точно раскрыть представления общественно-политического дискурса США о методах и приёмах взаимодействия США и колониальных империй после Первой мировой войны.

Завершение Первой мировой войны и Версальский договор оказали самое серьёзное влияние на содержание колониальной дискуссии, которая велась в американской прессе: кроме традиционного набора вопросов об архаичности колониальной системы, необходимости создания национальных государств в 